\title{
Streptomyces acidiscabies sp. nov. $\dagger$
}

\author{
D. H. LAMBERT ${ }^{1 *}$ AND R. LORIA ${ }^{2}$ \\ Department of Botany and Plant Pathology, University of Maine, Orono, Maine 04469, ${ }^{1}$ and Department of Plant \\ Pathology, Cornell University, Ithaca, New York $14853^{2}$
}

\begin{abstract}
A new bacterial species is described, for which we propose the name Streptomyces acidiscabies. This organism causes a scab disease of potatoes (Solanum tuberosum) which may occur in soils with pH values below 5.2. The acid scab symptoms caused by this organism are indistinguishable from the symptoms of commn scab caused by Streptomyces scabies. In culture, $\boldsymbol{S}$. acidiscabies is distinct from $\boldsymbol{S}$. scabies, having flexuous spore chains, a growth medium-dependent spore mass color ranging from white to organish red, and a red or yellow, pH-sensitive diffusible pigment rather than melanin. S. acidiscabies grows on agar media at pH 4.0 (versus pH 5.0 for $S$. scabies), does not use raffinose as a carbon source, and tolerates higher concentrations of crystal violet $(0.5 \mu \mathrm{g} / \mathrm{ml})$, thallium acetate $(10 \mu \mathrm{g} / \mathrm{ml})$, streptomycin $(20 \mu \mathrm{g} / \mathrm{ml})$, oleandomycin $(25 \mu \mathrm{g} / \mathrm{ml})$, and penicillin $\mathrm{G}$ $(10 \mathrm{IU} / \mathrm{ml}$ ) than $S$. scabies. The type strain of $S$. acidiscabies is strain RL-110 (= ATCC 49003).
\end{abstract}

Potato scab diseases are caused by several Streptomyces spp., among which Streptomyces scabies predominates. This species is revived and redefined in the accompanying paper (8). Scab diseases are characterized by corky tuber lesions, which may be superficial or pitted. Common scab is generally controlled by maintainance of a soil pH below 5.2. An indistinguishable form of the disease (acid or uncommon scab), which occurs in soils with $\mathrm{pH}$ values as low as 4.5 , was first detected in Maine in 1953. Early outbreaks of this disease were often associated with a particular Midwestern seed lot of the very susceptible variety 'Chippewa', suggesting that the pathogen was not native to Maine. However, there were also instances of the disease on farms which used no outside seed sources. Discontinuation of harsh types of seed treatment in the early $1950 \mathrm{~s}$ may have led to the build-up of indigenous pathogens to perceptible levels in such cases, as the acid-tolerant species persists primarily on infected tubers rather than in soil (10). Strains of Streptomyces species causing this form of the disease were isolated and described by Bonde and McIntyre (2) and by Manzer et al. (10), who found differences between typical and acid scab strains in pigment, raffinose usage, spore chain morphology, and tolerance of low soil $\mathrm{pH}$ values. The work of these authors and the protein electrophoresis characterizations of Hughes et al. (4) demonstrated that the organisms causing acid scab are distinct from those causing common scab in phenotype and ecology. Acid scab is now present in various areas of the Northeast (R. Loria, B. A. Kempter, and A. A. Jamieson, Am. Potato J. 63:440, 1986) and upper Midwest. In this paper, we provide additional descriptions of acid scab strains and propose for them the name Streptomyces acidiscabies.

\section{MATERIALS AND METHODS}

Strains. The cultures of Streptomyces species investigated included the following four acid scab strains recently isolated by Loria et al. (Am. Potato J. 63:440, 1986): strains RL-104 (from New York), RL-45, RL-110 (= ATCC $\left.49003^{\mathrm{T}}\right)(\mathrm{T}=$ type strain), and RL-182 (from Maine). The criteria used to select these strains from a much larger isolate collection were inability to use raffinose, flexuous spore

\footnotetext{
* Corresponding author.

† Maine Agricultural Experiment Station external publication 1367.
}

chains, and tolerance of an agar medium having a pH of 4.0. The pathogenicity of these strains was verified on tubers produced from stem cuttings (9). A fifth acid-tolerant strain, strain U30 (= ATCC 49004), was also included; this strain was isolated in Maine in the 1960s and was used as a standard in previous studies (10). The five acid-tolerant strains were compared with the following five typical $S$. scabies strains (pathogenic, melanin-producing, raffinoseusing organisms with spiral spore chains) that were isolated and characterized at the same time: strains RL-39 and RL-42 from New York, strains RL-70 and RL-174 from Maine, and strain RL-151 from New Brunswick, Canada. The following three additional strains were included: Streptomyces tendae ATCC $19812^{\mathrm{T}}$, which was considered by Hutter (5) to be similar to certain common scab strains; strain ATCC 10246, a pathogen that has been transferred to Streptomyces griseus (3); and the erroneous (7) "S. scabies" neotype strain IMRU 3018 (= ISP 5078) (15). The last two strains were included to represent common scab strains not covered by the original species description. (Quotation marks indicate that a strain does not belong in the revived species $S$. scabies [8].)

Strain characterization. International Streptomyces Project methods (13) were used to determine spore surface morphology, spore chain morphology, melanin and soluble pigment formation, and carbohydrate usage. The predominant spore mass pigment was described with a single color and with an additional modifying color in some instances. To determine whether they could be used as carbon sources, simple sugars and polysaccharides were filter sterilized and added to basal agar medium at concentrations of $1.0 \%$ (wt/vol). Basal medium contained (per liter) $2.64 \mathrm{~g}$ of $\left(\mathrm{NH}_{4}\right)_{2} \mathrm{SO}_{4}, 2.38 \mathrm{~g}$ of $\mathrm{KH}_{2} \mathrm{PO}_{4}, 5.65 \mathrm{~g}$ of $\mathrm{K}_{2} \mathrm{H}_{2} \mathrm{PO}_{4} \cdot 3 \mathrm{H}_{2} \mathrm{O}$, $1.00 \mathrm{~g}$ of $\mathrm{MgSO}_{4} \cdot 7 \mathrm{H}_{2} \mathrm{O}, 6.4 \mathrm{mg}$ of $\mathrm{CuSO}_{4} \cdot 5 \mathrm{H}_{2} \mathrm{O}, 1.1 \mathrm{mg}$ of $\mathrm{FeSO}_{4} \cdot 7 \mathrm{H}_{2} \mathrm{O}, 7.9 \mathrm{mg}$ of $\mathrm{MnCl}_{2} \cdot \mathrm{H}_{2} \mathrm{O}, 1.5 \mathrm{~g}$ of $\mathrm{ZnSO}_{4} \cdot 7 \mathrm{H}_{2} \mathrm{O}$, and $15.0 \mathrm{~g}$ of agar; the $\mathrm{pH}$ was 6.9 (12). The toxicities of inhibitory compounds were determined on modified Bennett agar containing (per liter) $1 \mathrm{~g}$ of beef extract, 1 $\mathrm{g}$ of yeast extract, $2 \mathrm{~g}$ of tryptone, $10 \mathrm{~g}$ of glycerol, and $15 \mathrm{~g}$ of agar. The toxic compounds tested were selected from those used by Williams et al. (20) and included penicillin $G$ $(10 \mathrm{IU} / \mathrm{ml})$, streptomycin sulfate $(20 \mu \mathrm{g} / \mathrm{ml})$, oleandomycin $(25 \mu \mathrm{g} / \mathrm{ml})$, thallous acetate $(10 \mu \mathrm{g} / \mathrm{ml})$, sodium chloride $(7 \%$, $w t / \mathrm{vol})$, and crystal violet $(0.5 \mu \mathrm{g} / \mathrm{ml})$. Additional concentrations of these chemicals or of other toxic compounds were screened, but our results are not reported below. The 


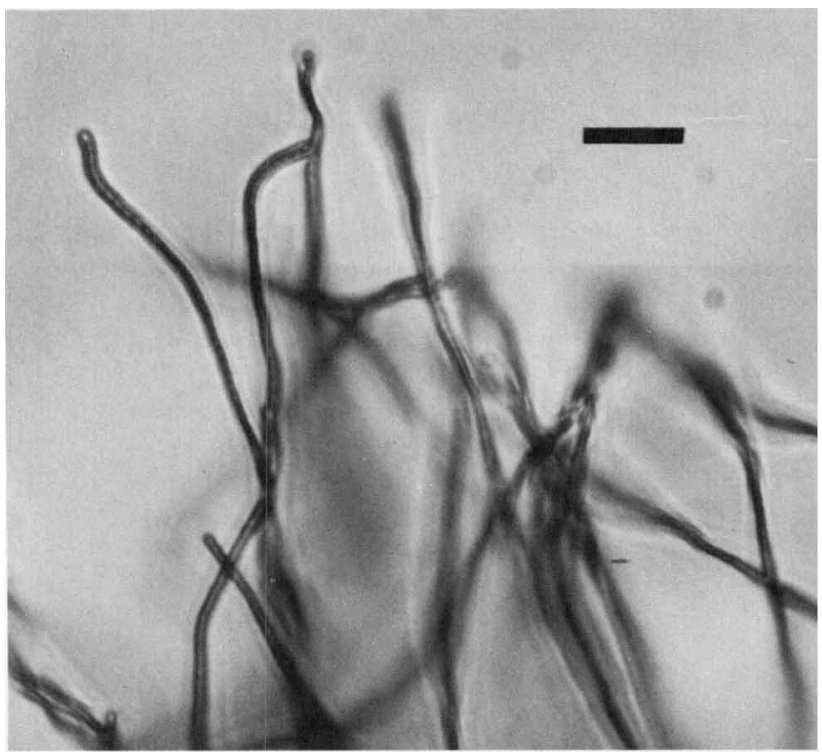

FIG. 1. Sporulating aerial mycelium of strain ATCC $49003^{\mathrm{T}}(=$ RL-110 ${ }^{\mathrm{T}}$ ): flexuous spore chains of an organism grown on yeast malt extract agar at $27^{\circ} \mathrm{C}$ for 14 days. Bar $=10 \mu \mathrm{m}$.

minimum $\mathrm{pH}$ that allowed growth was determined on media containing $10.0 \mathrm{~g}$ of dextrose per liter, $0.5 \mathrm{~g}$ of $\mathrm{L}$-asparagine per liter, $15.0 \mathrm{~g}$ of agar per liter, and $40 \mathrm{mM}$ phosphate as the monopotassium, dipotassium, and disodium salts to adjust the $\mathrm{pH}$ in $0.5-\mathrm{U}$ intervals from 3.5 to 8.5 (19). For inoculation of agar plates, spores were scraped from salts starch medium plates, suspended in $0.001 \%$ Triton X-100, filtered through sterile glass wool, washed, suspended in water, and spread in a single line by using a micropipette. Growth was evaluated after 14 days.

Wall composition (DL- and LL-diaminopimelic acid isomers) was determined by the method of Becker et al. (1). A diffusible pigment was produced by $S$. acidiscabies in modified salts starch agar or broth containing (per liter) $10.0 \mathrm{~g}$ of soluble starch (or glycerol), $1.0 \mathrm{~g}$ of $\mathrm{NaNO}_{3}, 1.0 \mathrm{~g}$ of $\mathrm{MgCO}_{3}$, $0.3 \mathrm{~g}$ of $\mathrm{K}_{2} \mathrm{PO}_{4}$, and $0.5 \mathrm{~g}$ of $\mathrm{NaCl}$, with or without $15.0 \mathrm{~g}$ of agar per liter (7). This pigment was concentrated from broth by a series of extractions in which we used $n$-butanol with alternating acidic and alkaline aqueous phases. The $\mathrm{pK}_{\mathrm{a}}$ of the pigment was determined photometrically in $0.05 \mathrm{M}$ phosphate buffer titrated with $\mathrm{HCl}$ or $\mathrm{NaOH}$ by measuring the absorbance at $420 \mathrm{~nm}$.

The phenotypes of the acid scab strains were compared with three taxonomic keys derived from the International Streptomyces Project $(6,11,18)$. Additional comparisons were made with the species descriptions of Shirling and Gottlieb (14-17) and Williams et al. (20).

\section{RESULTS}

The five $S$. acidiscabies strains are distinct from typical $S$. scabies isolates, from two atypical scab strains (strains IMRU 3018 and ATCC 10246), from $S$. tendae ATCC $19812^{\mathrm{T}}$, and from descriptions of other previously recognized species.

Morphological characteristics. On all standard agar media, the aerial mycelium of $S$. acidiscabies cultures was sympodially branched and formed flexuous spore chains (Fig. 1) which rarely curled at the tip. Fragmentation of the substrate mycelium, sporangium or sclerotium formation, and flagellated spores were not observed. The spores were smooth

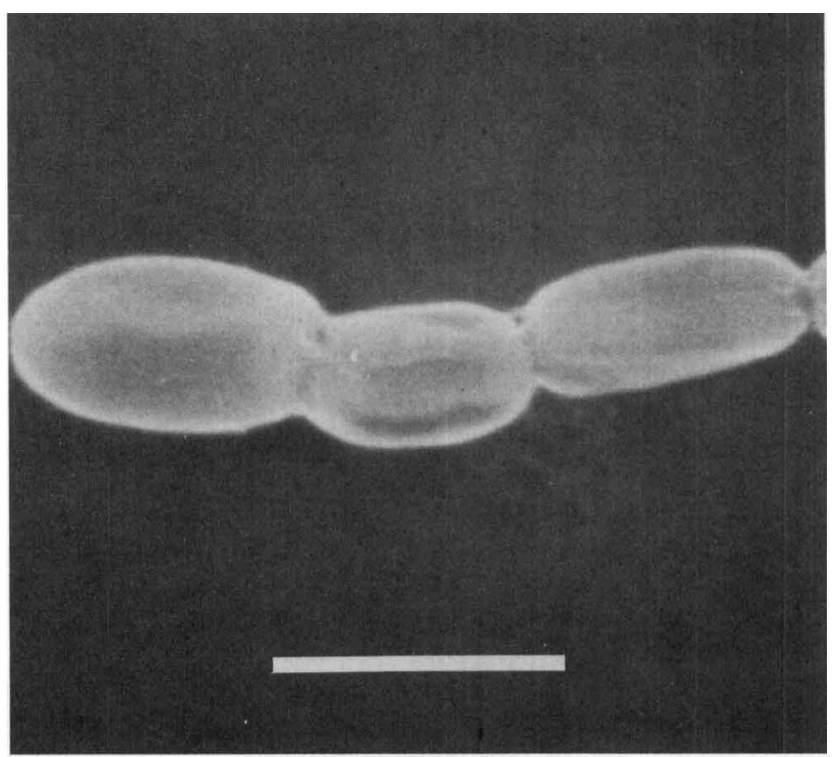

FIG. 2. Smooth spores of strain ATCC $49003^{\mathrm{T}}\left(=\mathrm{RL}-110^{\mathrm{T}}\right)$ grown on inorganic salts starch agar at $27^{\circ} \mathrm{C}$ for 14 days. Scanning electron micrograph. Bar $=1 \cdot \mu \mathrm{m}$.

and cylindrical, 0.4 to $0.5 \mu \mathrm{m}$ in diameter by 0.9 to $1.1 \mu \mathrm{m}$ long (Fig. 2); occasionally they were as short as $0.6 \mu \mathrm{m}$. The cell walls contained the LL-diaminopimelic acid isomer.

Pigments. S. acidiscabies strains did not produce melanoid pigments on tyrosine or peptone iron agar media (Table 1). When they were mass inoculated onto modified Kutzner inorganic salts glycerol agar, all five strains produced a dark red diffusible pigment which turned yellow when it was acidified with $1 \mathrm{~N} \mathrm{HCl}$ and then red again when it was treated with $1 \mathrm{~N} \mathrm{NaOH}$. Maximum pigment production occurred with $1 \%(\mathrm{wt} / \mathrm{vol})$ glycerol rather than starch. The $\mathrm{pK}_{\mathrm{a}}$ of the extracted pigment was 8.3. Depending on the medium, spore masses were white to salmon pink (Table 1). If concentrated by centrifugation, spores from pink colonies appeared to be dark red. S. tendae produced a dissimilar yellow pigment on various media. On the glucose asparagine medium used to determine responses to different $\mathrm{pH}$ values, this pigment was bright yellow and diffused at ca. $\mathrm{pH} 6.5$ and above, but was more orange and immobile below this $\mathrm{pH}$.

Physiological characteristics. The responses of $S$. acidiscabies and $S$. scabies strains were uniform within their respective groups. On Pridham-Gottlieb basal medium, $S$. acidiscabies used L-arabinose, D-fructose, D-glucose, i-inositol, D-mannitol, rhamnose, sucrose, and D-xylose but not raffinose as sole carbon sources (Table 1). The responses of the strains to toxic compounds also had differential value. In summary, $S$. acidiscabies cultures were distinct from all other cultures in spore color, diffusible pigment production, acid tolerance, and at least four additional criteria (Table 1). The five $S$. acidiscabies strains were further characterized in order to compare them with a numerical taxonomy scheme of the genus Streptomyces (20). All of the strains had the ability to degrade arbutin, polygalacturonate (at $\mathrm{pH} 7.3$ ), starch, xanthine, and xylan. They also had the ability to use as sole nitrogen sources L-hydroxyproline, L-histidine, Lmethionine, and L-valine. Only strains RL-45, RL-104, and RL-110 ${ }^{\mathrm{T}}$ were able to use L-phenylalanine. Only strain RL-45 was able to use salicin as a sole carbon source. Growth did not occur in agar media containing $10 \mu \mathrm{g}$ of sodium azide per $\mathrm{ml}, 1 \mu \mathrm{g}$ of crystal violet per $\mathrm{ml}$, or $7 \%$ 
TABLE 1. Characteristics of $S$. acidiscabies and other species

\begin{tabular}{|c|c|c|c|c|c|}
\hline Characteristic & $\begin{array}{c}\text { S. acidiscabies } \\
\text { isolates }\end{array}$ & $\begin{array}{l}\text { S. scabies } \\
\text { isolates }\end{array}$ & $\begin{array}{c}\text { S. tendae } \\
\text { ATCC } 19812^{\mathrm{T}}\end{array}$ & $\begin{array}{l}\text { "S. scabies" } \\
\text { IMRU } 3018\end{array}$ & $\begin{array}{c}\text { S. griseus } \\
\text { ATCC } 10246\end{array}$ \\
\hline \multicolumn{6}{|l|}{ Spore mass color on ${ }^{a}$ : } \\
\hline Salts starch medium & $\mathrm{W}(\mathrm{O}, \mathrm{Gy})$ & Gy & Gy & Gy & Gy \\
\hline Oatmeal medium & $\mathrm{W}(\mathrm{O})$ & Gy(Y) & Gy & Gy & Gy \\
\hline Glycerol asparagine medium & $\mathrm{W}(\mathrm{O}, \mathrm{Gy})$ & $\mathrm{Gy}(\mathrm{Y}, \mathrm{B})$ & Gy & Gy & Gy \\
\hline Yeast malt medium & $\mathrm{W}(\mathrm{O}, \mathrm{Gy})$ & Gy(Br) & Gy & Gy & $(\mathrm{Y}) \mathrm{W}$ \\
\hline \multicolumn{6}{|l|}{ Reverse mycelium color on ${ }^{a}$ : } \\
\hline Salts starch medium & $\mathrm{Br}, \mathrm{Gy}(\mathrm{Y})$ & $\mathrm{Gy}(\mathrm{Y})$ & $\mathrm{Y}$ & Gy & $(\mathrm{Br}) \mathrm{W}$ \\
\hline Oatmeal medium & $\operatorname{Br}(Y)$ & $\mathrm{Gy}(\mathrm{Y}, \mathrm{Br})$ & Gy & (B)Gy & (Y)W \\
\hline Glycerol asparagine medium & $\operatorname{Br}(\mathrm{Y})$ & Gy(Y) & $\mathrm{Y}$ & (B)Gy & $(\mathrm{Br}) \mathrm{W}$ \\
\hline Yeast malt medium & $\operatorname{Br}(Y)$ & $\operatorname{Br}(Y, G y)$ & $\mathrm{Y}$ & Gy & $(\mathrm{Y}) \mathrm{W}$ \\
\hline Spore chain morphology & Flexuous & Spiral & Flexuous & Flexuous & Flexuous \\
\hline Spore ornamentation & Smooth & Smooth & Smooth & Smooth $^{b}$ & $\mathbf{N A}^{c}$ \\
\hline Melanin from tyrosine & - & + & - & - & - \\
\hline Pigment on peptone iron medium & - & + & - & - & - \\
\hline Diffusible pigment $^{a}$ & $\mathrm{R} / \mathrm{Y}^{d}$ & - & $\mathrm{Y} / \mathrm{O}$ & - & - \\
\hline DAP optical isomer ${ }^{e}$ & $\mathbf{L L}$ & LL & LL & $\mathbf{L} \mathbf{L}$ & $\mathbf{L L}$ \\
\hline \multicolumn{6}{|l|}{ Carbon source usage } \\
\hline L-Arabinose $(1 \%, \mathrm{wt} / \mathrm{vol})$ & + & + & + & + & + \\
\hline D-Fructose $(1 \%, \mathrm{wt} / \mathrm{vol})$ & + & + & + & + & + \\
\hline D-Glucose $(1 \%, \mathrm{wt} / \mathrm{vol})$ & + & + & + & + & + \\
\hline D-Mannitol $(1 \%$, wt/vol) & + & + & + & + & + \\
\hline Raffinose $(1 \%$, wt $/ \mathrm{vol})$ & - & + & - & - & - \\
\hline Rhamnose $(1 \%, \mathrm{wt} / \mathrm{vol})$ & + & + & + & + & - \\
\hline Sucrose $(1 \%, \mathrm{wt} / \mathrm{vol})$ & + & + & - & - & + \\
\hline D-Xylose $(1 \%, \mathrm{wt} / \mathrm{vol})$ & + & + & + & + & - \\
\hline meso-Inositol $(1 \%, \mathrm{wt} / \mathrm{vol})$ & + & + & + & - & - \\
\hline Minimum $\mathrm{pH}$ for growth & 4.0 & 5.0 & 4.5 & 5.5 & 5.5 \\
\hline \multicolumn{6}{|l|}{ Growth in the presence of: } \\
\hline Thallium acetate $(100 \mu \mathrm{g} / \mathrm{ml})$ & - & - & - & - & + \\
\hline Thallium acetate $(10 \mu \mathrm{g} / \mathrm{ml})$ & + & - & + & + & + \\
\hline Sodium chloride $(7 \%, \mathrm{wt} / \mathrm{vol})$ & - & - & + & + & + \\
\hline Crystal violet $(0.5 \mu \mathrm{g} / \mathrm{ml})$ & + & - & + & + & - \\
\hline Phenol $(0.1 \%$, wt/vol $)$ & + & - & + & + & + \\
\hline Penicillin G (10 IU/ml) & + & - & + & + & + \\
\hline Oleandomycin $(100 \mu \mathrm{g} / \mathrm{ml})$ & - & - & + & - & + \\
\hline Oleandomycin $(25 \mu \mathrm{g} / \mathrm{ml})$ & t & - & + & + & + \\
\hline Streptomycin $(20 \mu \mathrm{g} / \mathrm{ml})$ & + & - & - & - & + \\
\hline
\end{tabular}

${ }^{a} \mathrm{~B}$, Blue; $\mathrm{Br}$, brown; $\mathrm{Bk}$, black; Gy, grey; $\mathrm{O}$, orange; $\mathrm{R}$, red; $\mathrm{W}$, white; $\mathrm{Y}$, yellow. Colors in parentheses indicate secondary hue(s) of predominant colors.

${ }^{b}$ Data from reference 13 .

${ }^{c}$ NA, Not available. Strain ATCC 10246 spores are presumed to be smooth.

${ }^{d}$ Color on alkaline media/color on acid media.

- DAP, Diaminopimelic acid.

$\mathrm{NaCl}$, but did occur in media containing $100 \mu \mathrm{g}$ of potassium tellurite per $\mathrm{ml}$. The methods used for these tests are described elsewhere $(8,20)$.

\section{DISCUSSION}

The five $S$. acidiscabies strains which we studied were nearly identical in their morphological and physiological characteristics. They differed perceptibly only in the degree of pigment production and the ability to grow on media containing salicin or phenylalaine as a sole carbon or nitrogen source. This uniformity may indicate that many acid scab strains in the northeastern United States are derived from a common source. Melanin is not produced by acid scab strains, which is further evidence that tyrosinase is not essential in the disease process. $S$. acidiscabies can grow on agar media at a lower $\mathrm{pH}$ than other scab-causing isolates (Table 1). Optimum growth, as evidenced by mycelium density and rate of colony development, occurred at $\mathrm{pH} 7$ and above, indicating that $S$. acidiscabies is acid tolerant rather than acidophilic. This is consistent with the ability of this species to cause disease of reduced severity in soils that are too acidic for $S$. scabies (2). The distinct differences between $S$. scabies and $S$. acidiscabies suggest that these two species are not closely related and that their ability to infect plants developed independently. When the percentages of traits held in common between $S$. acidiscabies and other scab pathogens or reference strains were calculated (8), little similarity was found. S. acidiscabies strains were most similar to Streptomyces setonii ATCC $25497^{\mathrm{T}}$ (a weak pathogen) and $S$. tendae ATCC $19812^{\mathrm{T}}$ (level of similarity, $80 \%$ in each case). The level of similarity to $S$. scabies was only $64 \%$. When $S$. acidiscabies was compared with the major Streptomyces groups of Williams et al. (20), no strong similarities were identified. $S$. acidiscabies was most similar to the following cluster groups: Streptomyces griseoruber (67\%), Streptomyces fulvissimus (65\%), Streptomyces aureofasciens (65\%), Streptomyces albidoflavus (64\%), and Streptomyces exfoliatus (63\%).

Streptomyces acidiscabies sp. nov. Streptomyces acidiscabies (ac.i.di.sca'bies. L. adj. acidus, acid; L. n. scabies, mange; acidiscabies, referring to the ability of the organism to cause acid scab of potatoes). Spores are 0.4 to 0.5 by 0.6 or 0.9 to $1.1 \mu \mathrm{m}$, smooth, and white (reddish on certain 
high-pH media) and are borne in mature flexuous chains containing 20 or more spores. A diffusible pigment is produced which is red above $\mathrm{pH} 8.3$ and golden yellow below $\mathrm{pH}$ 8.3. Melanin is not produced. L-Arabinose, D-fructose, D-glucose, D-mannitol, rhamnose, sucrose, and D-xylose are used as carbon sources, but not raffinose is not. The guanineplus-cytosine content of this species is $71 \mathrm{~mol} \%$. S. acidiscabies differs from all other streptomycetes that cause typical raised or pitted symptoms and have white spores, red pigment, and acid tolerance. It differs in at least one major characteristic from all other strains described in the International Streptomyces Project having red pigments or spores. Species characteristics, including those which differentiate $S$. acidiscabies from other pathogens, are shown in Table 1. $S$. acidiscabies is placed in the genus Streptomyces, as it possesses typical morphology and cell walls with the LLdiaminopimelic acid isomer. To date, $S$. acidiscabies has been isolated only from potatoes (Solanum tuberosum), and its pathogenicity on other species has not been determined. The ability of this species to persist in soil is relatively poor, and it is usually transmitted by infected seed tubers (10). The five strains which we studied (strains RL-45, RL-104, RL$110^{\mathrm{T}}\left[=\right.$ ATCC $49003^{\mathrm{T}}$ ], RL-182, and U30 [= ATCC 49004]) are presently the only examples of the species in culture. Specific characteristics of type strain RL-110 (= ATCC 49003) are listed in Table 1 or are mentioned above. The phenotypes of other strains studied previously by Bonde and McIntrye (2) are in agreement with the phenotype described here. All strains appear to differ very little from each other.

\section{ACKNOWLEDGMENTS}

We thank Hubert Lechevalier for providing strain IMRU 3018, Barbara Kempter and Amy Jamieson for preliminary characterizations of the recently isolated strains, Beth Hazen for the light micrograph, Susan Hunter for the electron micrograph, and Frank Healy for guanine-plus-cytosine content determinations.

\section{LITERATURE CITED}

1. Becker, B., M. P. Lechevalier, R. E. Gordon, and H. A. Lechevalier. 1964. Rapid differentiation between Nocardia and Streptomyces by paper chromotography of whole-cell hydrolysates. Appl. Microbiol. 12:421-423.

2. Bonde, M. R., and G. A. McIntyre. 1968. Isolation and biology of a Streptomyces sp. causing potato scab in soils below pH 5.0 . Am. Potato J. 45:273-278.

3. Gordon, R. E., and C. Horan. 1968. A piecemeal description of Streptomyces griseus (Krainsky) Waksman and Henrici. J. Gen. Microbiol. 50:223-233.

4. Hughes, C., R. C. McCrum, and F. E. Manzer. 1971. Protein and esterase electrophoretic patterns of Streptomyces spp. isolated from Maine potatoes. Am. Potato J. 48:206-213.

5. Hütter, R. 1967. Systematic der Streptomyceten. Karger, Basel.

6. Küster, E. 1972. Simple working key for the classification and identification of named taxa included in the International Streptomyces Project. Int. J. Syst. Bacteriol. 22:139-148.

7. Kutzner, H. J. 1979. The family Streptomycetaceae, p. 20282090. In M. P. Starr, H. Stolp, H. G. Trüper, A. Balows, and H. G. Schlegel (ed.), The prokaryotes. Springer-Verlag, Berlin.

8. Lambert, D. H., and R. Loria. 1989. Streptomyces scabies sp. nov., nom. rev. Int. J. Syst. Bacteriol. 39:387-392.

9. Loria, R., and B. A. Kempter. 1986. Relative resistance of potato tubers produced from stem cuttings and seed-piecepropagated plants to Streptomyces scabies. Plant Dis. 70: 1146-1148.

10. Manzer, F. E., G. A. McIntyre, and D. C. Merriam. 1977. A new potato scab problem in Maine. Maine Life Sci. Agric. Exp. Stn. Bull. 85:1-24.

11. Nonomura, H. 1974. Key for classification and identification of 458 species of the streptomycetes included in the ISP. J. Ferment. Technol. 52:78-92.

12. Pridham, T. G., and D. Gottlieb. 1948. The utilization of carbon compounds by some Actinomycetales as an aid for species determination. J. Bacteriol. 56:107-114.

13. Shirling, E. B., and D. Gottlieb. 1966. Methods for characterization of Streptomyces species. Int. J. Syst. Bacteriol. 16: 313-340.

14. Shirling, E. B., and D. Gottlieb. 1968. Cooperative description of type cultures of Streptomyces. II. Species descriptions from first study. Int. J. Syst. Bacteriol. 18:69-189.

15. Shirling, E. B., and D. Gottlieb. 1968. Cooperative description of type cultures of Streptomyces. III. Additional species descriptions from first and second studies. Int. J. Syst. Bacteriol. 18:279-391.

16. Shirling, E. B., and D. Gottlieb. 1969. Cooperative description of type cultures of Streptomyces. IV. Species descriptions from the second, third, and fourth studies. Int. J. Syst. Bacteriol. 19:391-512.

17. Shirling, E. B., and D. Gottlieb. 1972. Cooperative description of type strains of Streptomyces. V. Additional descriptions. Int. J. Syst. Bacteriol, 22:265-394.

18. Szabo, I. M., M. Marton, I. Buti, and C. Fernandez. 1975. A diagnostic key for the identification of "species" of Streptomyces and Streptoverticillium included in the International Streptomyces Project. Acta Bot. Acad. Sci. Hung. 21:387-418.

19. Williams, S. T., F. L. Davies, C. I. Mayfield, and M. R. Khan. 1971. Studies on the ecology of actinomycetes in soil. II. The $\mathrm{pH}$ requirements of streptomycetes from two acid soils. Soil Biol. Biochem. 3:187-195.

20. Williams, S. T., M. Goodfellow, G. Alderson, E. M. H. Wellington, P. H. A. Sneath, and M. J. Sackin. 1983. Numerical classification of Streptomyces and related genera. J. Gen. Microbiol. 129:1743-1813. 